\title{
Influence of biological products on the growth and development of large-fruited cranberry under greenhouse conditions
}

\author{
Edyta Derkowska*, Lidia Sas Paszt, Eugeniusz Szwonek \\ Research Institute of Horticulture \\ Konstytucji 3 Maja 1/3 \\ 96-100 Skierniewice, Poland
}

\begin{abstract}
The aim of this study was to determine the influence of various biological fertilizers on the growth and development of plants of the large-fruited cranberry and the degree of mycorrhizal association in their roots under controlled conditions. Plants of the 'Pilgrim', 'Stevens' and 'Ben Lear' cranberry cultivars were planted in rhizoboxes filled with soils collected from the areas of Krojczyn and Motoga. The following experimental treatments with fertilizers were applied: control plants, plants fertilized with NPK, a bacterial-mycorrhizal consortium, Vinassa, lignite + Vinassa, Florovit Natura and the fertilizer Crop-UP. The study has shown that there was a tendency to stimulate the vegetative growth and development of cranberry plants through the use of bio-fertilizers and beneficial fungi obtained from the rhizosphere of these plants. There was a tendency for the fresh and dry weight of cranberry shoots to increase, especially in 'Ben Lear', under the influence of the bio-fertilizer Florovit Natura when compared with the control plants fertilized with NPK. Compared with the NPK control, all of the bio-fertilizers significantly increased mycorrhizal frequency in the roots of the tested plants of the large-fruited cranberry, with the exception of Crop-UP and lignite compost used in conjunction with Vinassa in 'Stevens'. No statistically significant differences were obtained for plant size and root colonisation by ericoid fungi in the plants grown in the soil from the areas of Motoga and Krojczyn.
\end{abstract}

Key words: Vaccinium macrocarpon Ait., ericoid mycorrhiza, plant growth, cultivars

\section{INTRODUCTION}

The large-fruited cranberry (Vaccinium macrocarpon L.) is a dwarf evergreen shrub of the heath family Ericaceae with a coppice-like growth habit (Stobnicka et al. 2011). Its fruit is characterized by a tart and sour flavour, and is thus not suitable for fresh consumption (Adamczak et al. 2011). However, its suitability for processing and its health-promoting qualities are the reason why its cultivation is becoming increasingly popular (Caruso et al. 1997, Borges et al. 2010).
Cranberry plants, like all plants of the heath family Ericaceae, require acidic soils with a low degree of mineralization (Świeczkowska et al. 2003). In such soil conditions, the growth and development of cranberry plants is optimal (Adamczak et al. 2011). An important element of the normal development of plants, in all fruit crops and thus also in the cultivation of cranberry, is the proper development of the root system and the activity of the processes and changes occurring in the rhizosphere, including those involving symbiotic mycorrhizal fungi and

\footnotetext{
*Corresponding author.

Tel.: +48 4683454 56; fax +48 4683332 28;

e-mail: edyta.derkowska@inhort.pl (E. Derkowska).
} 
rhizosphere bacteria (Sas Paszt and Żurawicz 2005, Sas Paszt et al. 2011). The meagre root system of cranberry plants is devoid of root hairs (Myers and Leake 1996). The role of exchanging nutrients, water, and other essential substances between the plant and soil is fulfilled by fine hair roots, on the surface of which mycorrhizal fungi develop, creating a network (Roper and Vorsa 1997, Schilder et al. 2002). Mycorrhizal fungi, taking part in many processes occurring in the rhizosphere, break down organic matter in the soil, thereby providing plants with insoluble phosphorus compounds, and increase the absorption of nitrogen from the soil (Sas Paszt et al. 2003). Restoration of the dominance of beneficial soil microflora, increasing the organic matter content of the soil, and the use of bio-fertilizers increase the mechanical stability of the soil and help improve nutrient uptake by plants (Zachariakis et al. 2001, Lizarazo et al. 2005). The aim of the work presented in this paper was to assess the influence of various biological fertilizers on the growth and development of plants of the large-fruited cranberry and the degree of mycorrhizal association in their roots under controlled conditions.

\section{MATERIAL AND METHODS}

Plants of three large-fruited cranberry cultivars, 'Pilgrim', 'Stevens' and 'Ben Lear', were planted in September 2011 in the Greenhouse Complex of the Institute of Horticulture in Skierniewice, in rhizoboxes filled with two types of soil, one taken from the locality of Krojczyn (soil pH 3.73) and the other from Motoga (soil pH 4.48). Two cranberry plants were planted in each rhizobox, which had a capacity of $2 \mathrm{~kg}$ of soil. The experiment included control plants (not fertilized with NPK or any biological products) and plants fertilized in the spring of each year as follows: NPK $(\mathrm{N}-$ in the form of ammonium nitrate $\mathrm{NH}_{4} \mathrm{NO}_{3}-2.04$ $\mathrm{g} \times$ rhizobox $^{-1}, \mathrm{P}-$ in the form of granular triple superphosphate $\mathrm{P}_{2} \mathrm{O}_{5}-3.80 \mathrm{~g} \times$ rhizobox $^{-1}, \mathrm{~K}-$ in the form of potassium nitrate $\mathrm{K}_{2} \mathrm{SO}_{4}-1.56 \mathrm{~g} \times$ rhizobox $\left.^{-1}\right)$; a bacterial-mycorrhizal consortium (three strains of bacteria together with a mycorrhizal inoculum produced by MYCOFLOR; plants were treated three times at weekly intervals after they resumed growing in March); Vinassa preparation (applied to the soil four times at weekly intervals, at a concentration of $1 \%$, after plants resumed growing in March); lignite + Vinassa (lignite at the beginning of the experiment at $200{\mathrm{~g} 2 \mathrm{~kg}^{-1}}^{-1}$ of soil, and Vinassa applied to the soil four times at weekly intervals, at a concentration of $1 \%$ after plants resumed growing in March); Florovit Natura preparation (applied to the soil in the spring of each year at $2 \mathrm{~g}^{2} \mathrm{~kg}^{-1}$ of soil after plants resumed growing in March); and the fertilizer Crop-UP (applied to the leaves in the spring of each year in three spray treatments with a $1 \%$ solution at weekly intervals after plants resumed growing in March). The plants were subjected to the following growing conditions: photoperiod 16/8 hours (day/night), light intensity $70 \mu \mathrm{M} \mathrm{m}^{-2} \mathrm{~s}^{-1}$, temperature $25 / 20^{\circ} \mathrm{C}$ and air humidity approx. 50\%.

The plants in every treatment of the experiment were grown in three replications (each represented by one rhizobox with two plants) in the following combinations:

1. Control (control plants not treated with NPK, without application of bio-products, with optimal nutrient content).

2. Control NPK $\left(\mathrm{NH}_{4} \mathrm{NO}_{3}-2.04 \mathrm{~g} \times\right.$ rhizobox $^{-1}$, $\mathrm{P}_{2} \mathrm{O}_{5}-3.80 \mathrm{~g} \times$ rhizobox $^{-1}, \mathrm{~K}_{2} \mathrm{SO}_{4}-1.56 \mathrm{~g}$ $\times$ rhizobox $^{-1}$ ).

3. Bacterial-mycorrhizal consortium (bacteria: Pi3A Rahnella aquatilis, N52AD Panoea $\mathrm{sp}$, Ps49A Pseudomonas fluorescens, mycorrhizal inoculum - product of Mykoflor ${ }^{\circledR}$, manufactured by Mykoflor Włodzimierz Szałański, Rudy 84, 24-130 Końskowola, Poland - containing 1,000,000 propagules of arbuscular mycorrhizal fungi: Glomus intraradices, G. mosseae, G. etunicatum).

4. Vinassa (produced by Lallemand Polska Sp. $\mathrm{z}$ o.o. waste from the production of baker's yeast).

5. Lignite + Vinassa (product of Spółka Górnictwa Węgla Brunatnego Bełchatów, the compost was prepared using lignite (C)).

6. Florovit Natura (product of Inco-Veritas; contains lignite, urea, potassium sulphate, ammonium phosphate, dolomite and molasses).

7. Crop-UP (product of Albion Advanced Nutrition, a derivative of amino acid chelates: magnesium, manganese, copper, iron and zinc and boric acid).

In order to assess the influence of the biological preparations on the growth characteristics of plants of the 'Pilgrim', 'Stevens' and 'Ben Lear' cranberry cultivars, samples of the plants were collected in October 2013 to determine their growth parameters. Samples of the roots were collected in July 2013 for an assessment of the degree of mycorrhizal association. 


\section{Assessment of plant growth characteristics}

In order to assess the growth characteristics of cranberry plants of the 'Pilgrim', 'Stevens' and 'Ben Lear' cultivars under the influence of the bio-preparations applied, the aboveground parts of the plants were cut off in the autumn (October) of 2013, and the following parameters were assessed by classical methods: fresh and dry weight of the aboveground parts of the plants, the number of shoots and shoot length (Tabs 1-4).

\section{Assessment of the colonisation of roots by mycorrhizal arbuscular fungi}

The sampled roots (10 $\mathrm{g}$ from each replication) were stained according to the method by Phillips and Hayman (1970). Root fragments were prepared for examination in the following steps:

1. Maceration and clearing of root tissues with $10 \%$ potassium hydroxide at $95^{\circ} \mathrm{C}-1$ hour.

2. Treatment with 5\% hydrogen peroxide -15 min.

3. Washing out roots from the solution of hydrogen peroxide with water $-5 \mathrm{~min}$.

4. Acidification of roots with $10 \%$ hydrochloric acid - 1 hour.

5. Staining of roots in $0.1 \%$ trypan blue at $80^{\circ} \mathrm{C}-1$ hour, left in water bath for $24 \mathrm{hrs}$.

6. Rinsing roots with water to remove excess dye -10 min.

7. Preservation and storage of roots in glycerol.

Next, microscopic specimens were prepared by selecting 30 root fragments at a time, each $1 \mathrm{~cm}$ long, which were laid out parallel to one another on a glass slide containing glycerine and crushed with a coverslip. Thus prepared histological specimens were examined using a Nikon 50i microscope (with $20 \times, 40 \times, 60 \times, 100 \times$ lenses) and photographic records of the observed coils of mycorrhizal mycelium were created. The assessment of the degree of colonisation of the roots was performed according to the Trouvelot (1986) method. The results were used to calculate mycorrhizal frequency (F\%) using the computer program MYCOCALC, available on the website: http://www2.dijon.inra.fr/mychintec-/ Mycocalcprg/download.html (Tab. 5).

\section{Statistical analysis}

The results were statistically analysed using a univariate analysis of variance in a random block design. Multiple comparisons of the means for the combinations were performed with Tukey's test at the significance level of $\mathrm{p}=0.05$ using STATISTICA v.10 software, StatSoft, Inc. 2011.

\section{RESULTS AND DISCUSSION}

The main directions of research with large-fruited cranberry plants include assessments of the healthenhancing properties of the fruit. Comparisons have been made of the effects of mineral (mainly N) fertilization on the growth and yielding of cranberry cultivars. However, there are few references on the effects of bio-fertilizers on the growth and yield of different cultivars of this species.

The authors' studies have shown that it is possible to stimulate the growth of cranberry plants by applying bio-fertilizers and beneficial fungi and bacteria obtained from the rhizosphere of these plants. The action of bio-fertilizers was also found to produce positive effects on plant growth, but the differences were not statistically significant. The application of bio-products was found to have a significant effect on the degree of mycorrhizal colonisation in the roots of the largefruited cranberry cultivars studied. There was a tendency for the fresh and dry weight of the shoots of the 'Ben Lear' cranberry cultivar to increase under the influence of the bio-fertilizer Florovit Natura, compared with the control plants fertilized with NPK, growing in the soil collected from the area of Motoga (Tabs 1 and 2). Applications of the bacterial-mycorrhizal consortium and the bio-fertilizers Crop-UP and Vinassa only slightly affected the increase in the fresh and dry weight of the shoots, and the differences were not statistically significant. By contrast, the lignite compost used in combination with Vinassa caused a decrease in these parameters compared with the control plants fertilized with NPK. The use of the preparation Vinassa in 'Stevens' significantly increased the fresh and dry weight of the shoots.

There was a tendency for the plants of the 'Ben Lear' cultivar growing in the soil collected from the area of Motoga to increase the number and length of shoots under the influence of the bio-fertilizers Crop-UP and Vinassa, which improved, to a small extent, these characteristics in comparison with the control plants fertilized with NPK, but the differences were not statistically significant (Tabs 3 and 4). The location from which the soil was collected for the experiments had no influence on the results obtained. Although the figures show that the plants growing in the soil from Motoga were characterized by twice as strong growth, in terms of the fresh and dry weight of shoots and a greater number and length of shoots, as the plants grown in the soil from Krojczyn, the differences in the effects of the bio-products on these characteristics 
Table 1. Effect of bio-products on the fresh weight $(\mathrm{g})$ of the aboveground part of large-fruited cranberry plants of the 'Stevens', 'Pilgrim' and 'Ben Lear' cultivars grown in soils collected from Krojczyn and Motoga. Measurements were carried out in October 2013

\begin{tabular}{lcccccc}
\hline \multirow{2}{*}{ Treatment } & \multicolumn{3}{c}{ Krojczyn } & \multicolumn{3}{c}{ Motoga } \\
\cline { 2 - 7 } & Stevens & Pilgrim & Ben Lear & Stevens & Pilgrim & Ben Lear \\
\hline Control & $23.33 \mathrm{a}-\mathrm{d}^{*}$ & $20.00 \mathrm{a}-\mathrm{c}$ & $18.33 \mathrm{ab}$ & $41.66 \mathrm{a}-\mathrm{c}$ & $40.00 \mathrm{a}-\mathrm{c}$ & $46.66 \mathrm{bc}$ \\
Control NPK & $21.66 \mathrm{a}-\mathrm{c}$ & $16.66 \mathrm{a}$ & $23.33 \mathrm{a}-\mathrm{d}$ & $33.33 \mathrm{a}-\mathrm{c}$ & $35.00 \mathrm{a}-\mathrm{c}$ & $33.33 \mathrm{a}-\mathrm{c}$ \\
Bacterial-mycorrhizal consortium & $23.33 \mathrm{a}-\mathrm{d}$ & $23.33 \mathrm{a}-\mathrm{d}$ & $23.33 \mathrm{a}-\mathrm{d}$ & $50.00 \mathrm{c}$ & $40.00 \mathrm{a}-\mathrm{c}$ & $48.33 \mathrm{c}$ \\
Vinassa & $30.00 \mathrm{~d}$ & $23.33 \mathrm{a}-\mathrm{d}$ & $23.33 \mathrm{a}-\mathrm{d}$ & $46.66 \mathrm{bc}$ & $46.66 \mathrm{bc}$ & $40.00 \mathrm{a}-\mathrm{c}$ \\
Lignite + Vinassa & $23.33 \mathrm{a}-\mathrm{d}$ & $21.66 \mathrm{a}-\mathrm{c}$ & $18.33 \mathrm{ab}$ & $26.66 \mathrm{ab}$ & $26.66 \mathrm{ab}$ & $23.33 \mathrm{a}$ \\
Florovit Natura & $23.33 \mathrm{a}-\mathrm{d}$ & $26.66 \mathrm{~cd}$ & $25.00 \mathrm{~b}-\mathrm{d}$ & $46.66 \mathrm{bc}$ & $48.33 \mathrm{c}$ & $53.33 \mathrm{c}$ \\
Crop-UP & $23.33 \mathrm{a}-\mathrm{d}$ & $25.00 \mathrm{~b}-\mathrm{d}$ & $25.00 \mathrm{~b}-\mathrm{d}$ & $35.00 \mathrm{a}-\mathrm{c}$ & $38.33 \mathrm{a}-\mathrm{c}$ & $45.00 \mathrm{bc}$ \\
\hline
\end{tabular}

*Means in columns marked with the same letter do not differ significantly at $\mathrm{p}=0.05$ according to Tukey's multiple range test

Table 2. Effect of bio-products on the dry weight $(\mathrm{g})$ of the aboveground part of large-fruited cranberry plants of the 'Stevens', 'Pilgrim' and 'Ben Lear' cultivars grown in soils collected from Krojczyn and Motoga. Measurements were carried out in October 2013

\begin{tabular}{lcccccc}
\hline \multirow{2}{*}{ Treatment } & \multicolumn{3}{c}{ Krojczyn } & \multicolumn{3}{c}{ Motoga } \\
\cline { 2 - 7 } & Stevens & Pilgrim & Ben Lear & Stevens & Pilgrim & Ben Lear \\
\hline Control & $8.13 \mathrm{a}-\mathrm{e}^{*}$ & $7.06 \mathrm{a}-\mathrm{c}$ & $5.91 \mathrm{a}$ & $16.91 \mathrm{a}-\mathrm{e}$ & $18.53 \mathrm{a}-\mathrm{e}$ & $19.90 \mathrm{~b}-\mathrm{e}$ \\
Control NPK & $7.03 \mathrm{a}-\mathrm{c}$ & $6.06 \mathrm{ab}$ & $8.53 \mathrm{a}-\mathrm{e}$ & $13.15 \mathrm{a}-\mathrm{d}$ & $14.93 \mathrm{a}-\mathrm{e}$ & $13.75 \mathrm{a}-\mathrm{e}$ \\
Bacterial-mycorrhizal consortium & $7.50 \mathrm{a}-\mathrm{d}$ & $8.15 \mathrm{a}-\mathrm{e}$ & $9.36 \mathrm{~b}-\mathrm{e}$ & $21.01 \mathrm{de}$ & $17.05 \mathrm{a}-\mathrm{e}$ & $20.61 \mathrm{c}-\mathrm{e}$ \\
Vinassa & $10.96 \mathrm{e}$ & $8.96 \mathrm{a}-\mathrm{e}$ & $8.31 \mathrm{a}-\mathrm{e}$ & $18.33 \mathrm{a}-\mathrm{e}$ & $19.21 \mathrm{a}-\mathrm{e}$ & $16.75 \mathrm{a}-\mathrm{e}$ \\
Lignite + Vinassa & $7.91 \mathrm{a}-\mathrm{e}$ & $8.28 \mathrm{a}-\mathrm{e}$ & $7.08 \mathrm{a}-\mathrm{c}$ & $10.80 \mathrm{a}-\mathrm{c}$ & $10.15 \mathrm{ab}$ & $9.35 \mathrm{a}$ \\
Florovit Natura & $8.33 \mathrm{a}-\mathrm{e}$ & $10.43 \mathrm{de}$ & $9.48 \mathrm{c}-\mathrm{e}$ & $18.65 \mathrm{a}-\mathrm{e}$ & $21.10 \mathrm{de}$ & $23.23 \mathrm{e}$ \\
Crop-UP & $8.36 \mathrm{a}-\mathrm{e}$ & $9.83 \mathrm{c}-\mathrm{e}$ & $10.28 \mathrm{c}-\mathrm{e}$ & $13.21 \mathrm{a}-\mathrm{d}$ & $16.28 \mathrm{a}-\mathrm{e}$ & $19.93 \mathrm{~b}-\mathrm{e}$ \\
\hline
\end{tabular}

*Explanation: see Table 1

were not statistically significant (Tabs 1-4). Świeczkowska et al. (2003) studied the effects of fertilizers on the growth and yielding of four large cranberry cultivars ('Ben Lear', 'Pilgrim', 'Searles' and 'Stevens'). They found that the most favourable dose was $10 \mathrm{~kg} \mathrm{~N}$ and $10 \mathrm{~kg} \mathrm{~K}$, particularly for 'Pilgrim' and 'Stevens'. Nitrogen and potassium fertilization did not significantly affect plant morphology, but it had a positive effect on yielding. Krzewińska et al. (2008) also studied the effects of mineral fertilization, organic matter and mycorrhizal inoculation on the growth and yielding of the 'Pilgrim' large-fruited cranberry cultivar. They found a positive effect of soil enrichment with organic matter as well as a beneficial effect of mycorrhizal fungi on the number and length of new

Table 3. Effect of bio-products on the number of shoots of large-fruited cranberry plants of the 'Stevens', 'Pilgrim' and 'Ben Lear' cultivars grown in soils collected from Krojczyn and Motoga. Measurements were carried out in October 2013

\begin{tabular}{lcccccc}
\hline \multirow{2}{*}{ Treatment } & \multicolumn{3}{c}{ Krojczyn } & \multicolumn{3}{c}{ Motoga } \\
\cline { 2 - 7 } & Stevens & Pilgrim & Ben Lear & Stevens & Pilgrim & Ben Lear \\
\hline Control & $6.0 \mathrm{a} *$ & $6.3 \mathrm{ab}$ & $7.6 \mathrm{ab}$ & $12.4 \mathrm{a}-\mathrm{d}$ & $15.9 \mathrm{~cd}$ & $14.1 \mathrm{a}-\mathrm{d}$ \\
Control NPK & $8.7 \mathrm{ab}$ & $5.6 \mathrm{a}$ & $9.4 \mathrm{ab}$ & $8.5 \mathrm{a}-\mathrm{c}$ & $10.3 \mathrm{a}-\mathrm{d}$ & $11.3 \mathrm{a}-\mathrm{d}$ \\
Bacterial-mycorrhizal consortium & $7.3 \mathrm{ab}$ & $6.0 \mathrm{a}$ & $7.6 \mathrm{ab}$ & $15.1 \mathrm{~b}-\mathrm{d}$ & $12.0 \mathrm{a}-\mathrm{d}$ & $13.9 \mathrm{a}-\mathrm{d}$ \\
Vinassa & $8.3 \mathrm{ab}$ & $7.0 \mathrm{ab}$ & $8.3 \mathrm{ab}$ & $12.6 \mathrm{a}-\mathrm{d}$ & $13.9 \mathrm{a}-\mathrm{d}$ & $10.9 \mathrm{a}-\mathrm{d}$ \\
Lignite + Vinassa & $6.5 \mathrm{ab}$ & $5.9 \mathrm{a}$ & $8.9 \mathrm{ab}$ & $10.3 \mathrm{a}-\mathrm{d}$ & $7.6 \mathrm{ab}$ & $7.5 \mathrm{a}$ \\
Florovit Natura & $7.7 \mathrm{ab}$ & $7.6 \mathrm{ab}$ & $8.9 \mathrm{ab}$ & $16.3 \mathrm{~cd}$ & $14.7 \mathrm{a}-\mathrm{d}$ & $17.3 \mathrm{~d}$ \\
Crop-UP & $6.3 \mathrm{ab}$ & $6.7 \mathrm{ab}$ & $10.2 \mathrm{~b}$ & $10.3 \mathrm{a}-\mathrm{d}$ & $14.4 \mathrm{a}-\mathrm{d}$ & $18.0 \mathrm{~d}$ \\
\hline
\end{tabular}

*Explanation: see Table 1 
Table 4. Effect of bio-products on the length $(\mathrm{m})$ of the shoots of large-fruited cranberry plants of the 'Stevens', 'Pilgrim' and 'Ben Lear' cultivars grown in soils collected from Krojczyn and Motoga. Measurements were carried out in October 2013

\begin{tabular}{lcccccc}
\hline \multirow{2}{*}{ Treatment } & \multicolumn{3}{c}{ Krojczyn } & \multicolumn{3}{c}{ Motoga } \\
\cline { 2 - 7 } & Stevens & Pilgrim & Ben Lear & Stevens & Pilgrim & Ben Lear \\
\hline Control & $8.62 \mathrm{ab} *$ & $8.03 \mathrm{ab}$ & $7.05 \mathrm{a}$ & $16.37 \mathrm{a}-\mathrm{d}$ & $18.81 \mathrm{a}-\mathrm{d}$ & $19.14 \mathrm{a}-\mathrm{d}$ \\
Control NPK & $9.43 \mathrm{ab}$ & $7.12 \mathrm{a}$ & $10.98 \mathrm{ab}$ & $12.93 \mathrm{a}-\mathrm{c}$ & $14.90 \mathrm{a}-\mathrm{d}$ & $15.00 \mathrm{a}-\mathrm{d}$ \\
Bacterial-mycorrhizal consortium & $9.01 \mathrm{ab}$ & $8.87 \mathrm{ab}$ & $10.63 \mathrm{ab}$ & $20.96 \mathrm{~cd}$ & $19.09 \mathrm{a}-\mathrm{d}$ & $20.25 \mathrm{~b}-\mathrm{d}$ \\
Vinassa & $12.64 \mathrm{~b}$ & $8.59 \mathrm{ab}$ & $10.67 \mathrm{ab}$ & $16.95 \mathrm{~cd}$ & $17.15 \mathrm{a}-\mathrm{d}$ & $16.56 \mathrm{a}-\mathrm{d}$ \\
Lignite + Vinassa & $10.29 \mathrm{ab}$ & $8.06 \mathrm{ab}$ & $9.40 \mathrm{ab}$ & $12.69 \mathrm{a}-\mathrm{c}$ & $11.38 \mathrm{ab}$ & $10.49 \mathrm{a}$ \\
Florovit Natura & $10.11 \mathrm{ab}$ & $11.42 \mathrm{ab}$ & $9.83 \mathrm{ab}$ & $18.18 \mathrm{a}-\mathrm{d}$ & $19.33 \mathrm{a}-\mathrm{d}$ & $21.36 \mathrm{~cd}$ \\
Crop-UP & $10.30 \mathrm{ab}$ & $10.73 \mathrm{ab}$ & $11.81 \mathrm{ab}$ & $13.41 \mathrm{a}-\mathrm{d}$ & $18.27 \mathrm{a}-\mathrm{d}$ & $22.44 \mathrm{~d}$ \\
\hline
\end{tabular}

*Explanation: see Table 1

Table 5. Effect of bio-products on mycorrhizal frequency (F\%) in the roots of large-fruited cranberry plants of the 'Stevens', 'Pilgrim' and 'Ben Lear' cultivars grown in soils collected from Krojczyn and Motoga. Measurements were carried out in October 2013

\begin{tabular}{lcccccc}
\hline \multirow{2}{*}{ Treatment } & \multicolumn{3}{c}{ Krojczyn } & \multicolumn{3}{c}{ Motoga } \\
\cline { 2 - 7 } & Stevens & Pilgrim & Ben Lear & Stevens & Pilgrim & Ben Lear \\
\hline Control & $11.11 \mathrm{a}^{*}$ & $15.56 \mathrm{a}$ & $11.11 \mathrm{a}$ & $16.67 \mathrm{a}$ & $13.33 \mathrm{a}$ & $16.67 \mathrm{ab}$ \\
Control NPK & $7.78 \mathrm{a}$ & $11.11 \mathrm{a}$ & $8.89 \mathrm{a}$ & $10.00 \mathrm{a}$ & $8.89 \mathrm{a}$ & $10.00 \mathrm{a}$ \\
Bacterial-mycorrhizal consortium & $27.78 \mathrm{~b}$ & $25.56 \mathrm{~b}$ & $33.33 \mathrm{~b}$ & $24.44 \mathrm{~b}$ & $28.89 \mathrm{~b}$ & $32.22 \mathrm{~b}$ \\
Vinassa & $21.11 \mathrm{~b}$ & $25.56 \mathrm{~b}$ & $31.11 \mathrm{~b}$ & $32.22 \mathrm{~b}$ & $21.11 \mathrm{~b}$ & $22.22 \mathrm{~b}$ \\
Lignite + Vinassa & $14.44 \mathrm{ab}$ & $21.11 \mathrm{ab}$ & $21.11 \mathrm{~b}$ & $16.67 \mathrm{a}$ & $17.78 \mathrm{~b}$ & $18.89 \mathrm{~b}$ \\
Florovit Natura & $42.22 \mathrm{c}$ & $41.11 \mathrm{c}$ & $46.67 \mathrm{c}$ & $40.00 \mathrm{c}$ & $40.0 \mathrm{c}$ & $38.89 \mathrm{c}$ \\
Crop-UP & $18.89 \mathrm{~b}$ & $27.78 \mathrm{~b}$ & $18.89 \mathrm{~b}$ & $17.78 \mathrm{a}$ & $17.78 \mathrm{~b}$ & $17.78 \mathrm{~b}$ \\
\hline
\end{tabular}

*Explanation: see Table 1

growth and the number of spurs in cranberry plants. Kaczmarska (2009) studied the growth, flowering and fruiting of six cultivars of the American cranberry (No. 20, 'Pilgrim', 'Cropper', 'Le Munion', 'Stevens' and 'Stankavich'). She demonstrated that the highest number of long shoots and the largest increase in the annual growth of long shoots per plant were shown by the cultivars 'Stankavich', 'Le Munion' and 'Pilgrim', while the cultivars 'Stevens' and 'Cropper' had the lowest values of these traits. The results of those studies are consistent with the results obtained in our work and indicate that the 'Stevens' cultivar was characterized by the highest number of long shoots and the largest annual increase in the length of long shoots compared with the 'Pilgrim' cultivar.

In the studies presented here, the roots of twoyear-old cranberry plants, fertilized with biofertilizers under greenhouse conditions, were found to be colonised at a level of $40 \%$ regardless of the cultivar tested, and were colonised by mycorrhizal fungi four times as intensely as the roots of the control plants. The highest mycorrhizal frequency was observed in the roots of cranberry plants of the 'Ben Lear' cultivar treated with the biofertilizer Florovit Natura and growing in the soil from the area of Krojczyn. In comparison with the NPK control, all of the bio-fertilizers significantly increased mycorrhizal frequency in the roots of the tested plants of the large-fruited cranberry, with the exception of Crop-UP and lignite compost used in conjunction with Vinassa in the 'Stevens' cultivar grown in the soil from Motoga, and in the 'Stevens' and 'Pilgrim' cultivars grown in the soil from Krojczyn under the influence of the lignite compost used together with Vinassa. The location from which the soil was collected for the experiments (Motoga, Krojczyn) did not significantly affect the level of mycorrhizal frequency in the roots of the cranberry cultivars studied (Tab. 5). Kosola et al. (2007) studied the effects of the cultivar, soil type, and the composition of mulches on the colonisation of roots by mycorrhizal fungi of 13 cranberry varieties. These factors were found to have no significant effect on mycorrhizal frequency in the roots of plants of the large-fruited cranberry. They found, 
however, that the degree of colonisation increased with the depth at which the roots were sampled. Scagel (2003) studied plants of the 'Stevens' cranberry cultivar, aged from two to thirty-eight years, grown conventionally and organically, for the presence of mycorrhizal fungi in the roots. She observed that the cultivation system (organic and conventional) had no effect on the colonisation of the roots of the large-fruited cranberry plants. The mycorrhizal fungi in the experiment conducted by Scagel (2003) colonised cranberry roots at a level dependant on the age of the plants: 2-10 years old $-\mathrm{F}=7.5 \% ; 10-12$ y.o. $-\mathrm{F}=28 \% ; 15-21$ y.o. $-\mathrm{F}=70 \% ; 32-38$ y.o. $\mathrm{F}=90 \%$. The results obtained by the authors of this paper indicate much higher values of mycorrhizal frequency after two years of running the experiment than the results obtained by Scagel (2003) in plants of a similar age.

The research on the effects of bio-products on the growth of cranberry plants will be continued, with particular emphasis on the size and quality of the crop produced, which will contribute to the development of sustainable fertilization methods for plants of this species.

\section{CONCLUSIONS}

1. There was a tendency for the vegetative growth characteristics of plants of the large-fruited cranberry to increase after the application of the bio-fertilizer Florovit Natura, compared with control plants fertilized with NPK.

2. In comparison with the control plants, the use of the bio-fertilizer Florovit Natura increased the degree of mycorrhizal colonisation in the roots of plants of the large-fruited cranberry.

3. There was no significant effect of the soil collected from the areas of Motoga and Krojczyn on the size of the plants and the degree of mycorrhizal colonisation in the roots of the large-fruited cranberry cultivars studied.

\section{ACKNOWLEDGEMENTS}

This work was partially supported by grant No. 7235/B/PO12011/40 of the National Science Centre, Poland, in 2011.

\section{REFERENCES}

Adamczak A., Buchwald W., KozŁowski J., 2011. Variation in the content of flavonols and main organic acids in the fruit of European cranberry (Oxycoccus palustris Pers.) growing in peatlands of North-Western Poland. Herb. Pol. 57(4): 5-15.
Borges G., Degeneve A., Mullen W., Crozier A., 2010. Identification of flavonoid and phenolic antioxidants in black currants, blueberries, raspberries, red currants, and cranberries. J. Agric. Food Chem. 58: 3901-3909.

Caruso F.L., Yarborough D.E., Smagula J.M., 1997. Trends in cranberry production. Acta Hort. 446: 41-45.

KACZMARSKA E., 2009. Growth, flowering and yielding of six American cranberry (Vaccinium macrocarpon Ait.) cultivars. Acta Sci. Pol., Hort. Cult. 8(4): 35-44.

Kosola K.R., Beth A.A., 2007. Mycorrhizal colonization of cranberry: Effects of cultivar, soil type, and leaf litter composition. J. Amer. Soc. Hort. Sci. 132(1): 134-141.

Krzewińska D., Borkowska B., Treder W., TryngielGAĆ A., 2008. Effect of some cultural practices on growth and yield of cranberry (Vaccinium macrocarpon Ait.): preliminary study. Proc. Int. Sci. Conf. "Sustainable Fruit Growing: From Plant to Product”, 28-31 May, Jūrmala-Dobele: 198-206.

Lizarazo L.M., Jordá J.D., JuÁrez M., SÁnchez-Andreu J., 2005. Effect of humic amendments on inorganic $\mathrm{N}$, dehydrogenase and alkaline phosphatase activities of a Mediterranean soil. Biol. Fert. Soils 42: 172-177.

Myers M.D., Leake J.R., 1996. Phosphodiesters as mycorrhizal P sources. II. Ericoid mycorrhiza and the utilization of nuclei as a phosphorus and nitrogen source byVaccinium macrocarpon. New Phytol. 132: 445-451.

Phillips J.M., HaYman D.A., 1970. Improved procedures for clearing roots and staining parasitic and vesiculararbuscular mycorrhizal fungi for rapid assessment of infection. Trans. Brit. Mycol. Soc. 55: 158-161.

Roper T.R., Vorsa N., 1997. Cranberry: botany and horticulture. Hort. Reviews 21: 215-249.

Sas L., Marschner H., Römheld V., Mercik S., 2003. Effect of nitrogen forms on growth and chemical changes in the rhizosphere of strawberry plants. Acta Physiol. Plant. 25(3): 241-247.

Sas Paszt L., Sumorok B., Malusá E., GŁuszek S., Derkowska E., 2011. The influence of bioproducts on root growth and mycorrhizal occurrence in the rhizosphere of strawberry plants 'Elsanta'. J. Fruit Ornam. Plant Res. 19(1): 13-34.

Sas PaszT L., Żurawicz E., 2005. Studies of the rhizosphere of strawberry plants at the Research Institute of Pomology and Floriculture in Skierniewice, Poland. Inter. J. Fruit Sci. 5(1): 115-126.

SCAGEL C.F., 2003. Mycorrhizal status of sand-based cranberry (Vaccinium macrocarpon) bogs in southern Oregon. Small Fruit Rev. 2: 31-41.

Schilder A.M.C., Olatinwo R.O., Hanson E.J., 2002. Fruit rots are common in commercial cranberry beds in Michigan, USA. Acta Hort. 574: 91-93.

Stobnicka A., Gniewosz M., Miętuszewska A., 2011. Antibacterial activity of cranberry, sea-buckthron, 
noni and wolfberry juices. Bromat. Chem. Toksykol. 3: 650-655.

Świeczkowska A., Kawecki Z., Stanys V., 2003. The influence of fertilizers on Vaccinium macrocarpon Ait. growth and yielding. 1. Phenophases, plant morphology and yielding. Žemès ūkio mokslai / Agricultural Sciences 4: 76-81.
Zachariakis M., Tzorakakis E., Kritsotakis I., Siminis C.I., Manios V., 2001. Humic substances stimulate plant growth and nutrient accumulation in grapevine rootstocks. Acta Hort. 549: 131-136.

Received February 4, 2015; accepted April 9, 2015 